\title{
FRÅN MASKIN TILL HOLOGRAM: - REFLEXIONER KRING MUSEERNAS ORGANISATION
}

\author{
Kim Forss
}

Det pågår en spännande debatt om vad ett museum är, vad det skall vara och vilken roll museerna skall spela $i$ samhället. Mitt syfte $i$ den här artikeln är dock inte att diskutera museernas mål eller deras samhällsuppdrag. Det kan räcka med att konstatera att uppdraget är komplext, och att det finns mainga skilda uppfattningar om vad det innehaller. Det visar inte minst remissvaren på museiutredningens betänkande "Minne och bildning» (SOU 1994:51) som Kulturdepartementet sammanställt. Oavsett detta är museerna också människor, byggnader, inventarier mm. De är organisationer som leds av sina styrelsers visioner, personalens ambitioner och publikens önskningar. Museerna pàverkas frän många hål, och parlamentariska museiutredningar är bara ett sädant. Organisationer är i sig föremål för studium, men organisationsteorin har - lika litet som museologin - nagon stark kärna av gemensamma synsätt på sitt studieobjekt. Under årens lopp har forskare besvarat frägorna om vad en organisation är, och hur den fungerar, på skilda sätt. I Thomas Kuhn's (1970) anda kan man tala om paradigmskiften, men det finns ingen enhetlig rörelse frän ett paradigm till andra inom organisationsvetenskapen. I det följande avser jag skildra några synsätt på organisationer.

Tre huvudtyper av metaforer skisseras; organisationen som (1) maskin, (2) levande system eller (3) hologram. Den metafor som anläggs får konsekvenser för mål och struktur, ledning, styrning och samordning. Frågan är då vilken metafor som är rådande inom museivärlden, och vad det făr för konsekvenser för de enskilda museernas såväl som museisystemets funktion.

\section{VAD ÄR EN ORGANISATION?}

Själva ordet «organisation» kommer från det grekiska organon, som betyder redskap eller instrument. Med det följer ett instrumentellt synsätt; organisationer är skapade för att uppnå mål, de är instrument för ett syfte. Människor har skapat organisationer för skilda syften, som t.ex. att bygga pyra- 
KIM FORSS

102 mider, resa katedraler, erövra imperier, men det är egentligen först genom den industriella revolutionen i Europa och Nordamerika som utvecklingen av kunskap om organisationen som fenomen tagit fart. Organisationer är gamla men vetenskapen om dem är ung.

\section{Organisationen som en maskin}

Den industriella revolutionens organisationer skapades för mekaniserat arbete; människors vanor behövde anpassas till maskiners sätt att fungera. Gamla hantverkstraditioner och familjebaserat arbete ändrades för att passa krav på effektivitet genom arbetsfördelning. Maskinerna såväl möjliggjorde som förutsatte nya former för styrning och kontroll.

Grundelementen i den vetenskap som växte fram kodifierades under 1700- och 1800 -talen av vetenskapsmän och praktiker som Adam Smith, Charles Babbage och Max Weber. De betonade fördelarna med specialisering av arbetsuppgifter, standardisering av rutiner och arbetssätt, regler för arbetsprocesser, definition av skilda hierarkiska nivåer samt klara och tydliga befälsprinciper och ansvarsförhållanden.

Med hjälp av metoder som dessa, kunde en organisation bli mera förutsägbar; snabbare, punktligare, tillförlitligare, effektivare. Organisationen i sin helhet skulle bli mera lika en maskin, och det var också bilden av en maskin som var idealet för hur en organisation skulle se ut.

Under 1900-talets första hälft utvecklades och förfinades kunskapen om organisation i den "klassiska" skolan av forskare som Henri Fayol, F.W. Mooney, Frederick Taylor och Lyndall Urwick. För dem alla var ingenjörsvetenskaperna och de militära organisationerna viktiga inspirationskällor. Deras tänkande om organisation inriktades på att skapa effektivitet genom processer för att planera, fördela arbete, fatta beslut, samordna och kontrollera arbetsprocesser. Utifrån deras forskning har många av företagsekonomins grundläggande tekniker vuxit fram, såsom strategisk planering, budgetering, mål- och resultatstyrning, med flera tekniker för rationellt beslutsfattande och kontroll.

Det grundläggande draget är att organisationen blir uppbyggd som en maskin, med specialiserade delar som fullgör skilda funktioner. Olika avdelningar skall förhålla sig till varandra som delarna $i$ en maskin. Aktiviteter följer på varandra i mekanisk ordning. Ansvarsförhållanden på olika nivåer skall passa in $\mathrm{i}$ varandra som kuggarna i två hjul. Fortfarande är detta arv från de klassiska managementteoretikerna förhärskande på de flesta utbildningar i företagsekonomi, organisation och ledarskap. Många tänker automatiskt (om än inte medvetet) inom ramen för maskinmetaforen när de konceptualiserar problem kring ledarskap och organisation.

Det är knappast någon tvekan om att maskinmetaforen varit ett kraftfullt instrument för att skapa framgångsrika företag och organisationer. Den ger en övertygande bild av organisation, och den är lätt att omsätta i normativa rekommendationer och praktisk handling. Det vittnar inte minst den överväldigande majoriteten av privata företag, offentliga organisationer, myndigheter $\mathrm{mm}$ som vi ser runt omkring oss. Men den har också svagheter: särskilt (a) genom att den skapar organisationsformer som har svårt att anpassa sig till förändringar, (b) den kan resultera $\mathrm{i}$ 
fördummande byråkrati, (c) den kan leda till ett kortsiktigt tänkande kring instrumentella värden snarare än organisationens ursprungliga mål, samt (d) den kan skapa omänskliga och hårda arbetsmiljöer, särskilt för dem på lägre nivåer i organisationspyramiden.

\section{Organisationen som ett levande system}

Allt eftersom forskningen gjorde framsteg, växte en ny bild av organisationers väsen fram. Man kunde observera att organisationer i praktiken såg mycket olika ut i skilda miljöer. Byråkratiska organisationer fungerar bäst i en stabil omvärld, medan andra former krävs i turbulenta, konkurrensutsatta miljöer.

Under de senaste 50 åren har teoretiker snarare haft biologin än ingenjörsvetenskapen som inspirationskälla. Genom metaforer som celler, komplexa organismer, arter, och ekologi, har man utvecklat en rad nya idéer och insikter om hur organisationer fungerar. Forskare har identifierat skilda typer av organisationsbehov vad avser strukturer och processer, man har granskat hur organisationer anpassar sig till omvärlden, man har urskiljt olika stadier i organisationers livscykler, faktorer som påverkar organisationens "hälsa", samt hur organisationer interagerar med miljön som öppna, levande system.

Utgångspunkten för den nya teoribildningen var egentligen en fokusering på enskilda människors anpassning på arbetsplatser. De välkända Hawthorne-studierna under Elton Mayo's ledning vid Western Electric i Chicago visade hur den formella "mekanistiska" organisationsstrukturen kompletterades av informella strukturer, vilka satte upp gränser för organisationens funktion, och utan vilka ingenting kunde fungera. Abraham Maslow visade hur 103 människors (hierarkiskt ordnade) behov och behovstillfredsställelse påverkade deras motivation på arbetsplatsen. Allt detta påverkade tänkandet kring organisationer bort från maskinmetaforen, och från 1950-talet inleddes en rad experiment för att skapa mera mänskliga organisationer, med bättre utrymme för initiativ och kreativitet (bl.a. på Scania och Volvo här i Sverige).

Genom att se organisationer som öppna system, fokuserades intresset på att skapa en samstämmighet mellan organisationers inre liv och den yttre verkligheten. De båda forskarna Paul Lawrence och Jay Lorsch visade hur skilda typer av marknader och olika tekniska produktionssystem leder till att företagen ser annorlunda ut. De visade också att företag som arbetar inom snabbt föränderliga och osäkra branscher tenderar att bli mera differentierade och specialiserade. Henry Mintzberg identifierade fem "urtyper» av organisationer, var och en med speciella interna karaktäristika passande för en specifik miljö.

Jämfört med den klassiska managementteorin har den här skisserade utvecklingen betytt mycket, framförallt för forskningen men även för praktiken. Bilden av organisationerna som ett slags levande väsen skapar i sig utrymme för större flexibilitet $\mathrm{i}$ handlingen, och den kan hjälpa till att fästa blicken på strategiska parametrar som omgivningens intressen och behov, och organisationens överlevnad. I maskinmetaforen står organisationens mål i centrum för intresset, men i bilden av det levande systemet står överlevnad i centrum. Därmed betonas organisationens ändamålsenlighet snarare än dess effektivitet. 
104 Men även den här metaforen har sina svagheter. I en viss bemärkelse är den väldigt konkret; den fäster uppmärksamheten på organisationer som påtagliga realiteter. Men organisationer är även kulturella fenomen, de är även upplevda, implicita verkligheter. De påverkar sin miljö och kan skapa överlevnadsmekanismer under mycket skilda omständigheter. Organismmetaforen är också funktionell, den bygger på att organisationer blir bra genom anpassning (och urval), men som vi vet är organisationer långt ifrån rationella. Inom forskningen har det med tiden formats nya metaforer för studieobjektet.

\section{Den holografiska organisationen}

Genom paralleller till nyvunnen kunskap om hur hjärnan fungerar, har nya insikter om organisationers väsen vunnits. Forskare har tagit sin utgångspunkt $\mathrm{i}$ organisationer som informationsbearbetande system. Kunskap om artificiell intelligens har också påverkat dem. Herbert Simon visade t.ex. hur schackspelare utformar effektiva strategier även under förutsättningar av "bounded rationality», dvs eftersom det är omöjligt att uppfylla den klassiska beslutsteorins krav på rationella överväganden, söker människan i praktiken andra vägar att fatta beslut.

Vid närmare studier visar det sig också att organisationer inte allid utformar strukturer och processer efter sin miljö; även på en och samma marknad kan man finna många skilda typer av organisationer. Fred Emery, Chris Argyris och Donald Schon fäste uppmärksamheten på organisationer som självorganiserande system, med förmåga att utvecklas och lära, samt att lära sig att lära för att förändra sig själva och sin miljö.
De organisationer som ovannämnda forskare studerade var mycket olika den klassiska management-teorins förebilder och den därpå följande teoribildningen. Forskarna kom att utveckla helt nya synsätt på vad som utgör en väl fungerande organisation, och några av deras begrepp vänder helt enkelt upp och ned på den klassiska management-teorin. Många har inspirerats av kaosteorin och den systemteoretiska utvecklingen av begreppet komplexitet (Mainzer, 1994; Waldrop, 1992).

Fred Emery och Eric Trist identifierade «redundans» som en central variabel. Det kan beskrivas som reservkapacitet, eller inbyggd förmåga att svara upp mot nya omständigheter. De menade att det effektivaste sättet att bygga in redundans i en organisation är att sprida den på alla delar. Hellre än att koncentrera funktioner och specialisera dem, bör alla organisationens delar kunna svara upp mot omvärldens krav. Ingen skall behöva hänvisa ett ärende till en kollega, eller svara en kund att «detta är inte mitt problem".

Snarare än att specialisera sig bör man bygga in så mycket variationsrikedom som möjligt $\mathrm{i}$ en och samma organisation. I princip borde all variation i omvärlden speglas internt i organisationen. Den som skapar organisationer bör inte heller specificera uppgifter, ansvar $\mathrm{mm}$ annat än till minsta möjliga grad. Det strider förstås helt mot klassisk teori som snarare säger att organisationer bör vara så precist detaljerade och reglerade som möjligt, och att ansvar bör vara klart och tydligt lokaliserat på hierarkiska nivåer. I den holografiska typen av organisation skall man snarare undvika hierarkiska nivåer. Principen för holografisk design bygger på att alla delarna av organisationen skall återspegla dess helhet. 


\section{Slutsats}

De här tre metaforerna visar hur organisationsteorin har utvecklats, men det är inte på något sätt en linjär utveckling. Den övervägande delen av praktiker, och många teoretiker, har minst en fot kvar i den klassiska teoribildningen. Man kan inte heller säga att de senare metaforerna ersätter de tidigare. Liksom i fysiken kan man snarare säga att de nya teorierna förklarar större delar av forskningsområdet, och att den gamla teorin inkorporeras som ett specialfall.

Den som har att ta sig an en organisation kan dra nytta av alla de tre metaforerna. Det finns även andra infallsvinklar på studiet av organisation - med konsekvenser för praktiken - men för tillfället stannar jag vid de här nämnda huvuddragen. För en närmare beskrivning av organisationsmetaforer hänvisas till Morgan (1986).

Vad har då detta med museerna att göra? Ja, frågan är vilken typ av organisationer de utgör - och vilken bild av organisationen de har som är anställda vid museerna. Svaret på frågan har betydelse för hur chefer agerar som ledare, och hur anställda tar ansvar för utställningar och möter museibesökare. Det har säkert mycket stor betydelse för museisystemets förändringsbenägenhet. Museiutredningen genomförde en stor enkät, riktad till samtliga anställda vid museerna, och enkätsvaren kan ge en viss vägledning om vilka metaforer som haft störst genomslagskraft.

\section{HUR SER MUSEIANSTÄLLDA PA ORGANISATIONEN?}

Syftet med museiutredningens enkät var att få ett bredare perspektiv på frågor som rör personal, kompetensutveckling, arbets- processer samt organisationsstruktur. Utredningen använde svenska museiföreningens adressregister. De svarande ombads ge sina synpunkter anonymt. De som besvarat enkäten är något fler kvinnor än män, båda grupperna med en medelålder över 40 (dock högre vad beträffar männen), med en hög utbildningsnivå och ofta med befattningar i museiledningen. De arbetar med kärnområdena vård, forskning och publikrelaterad verksamhet. Vad har de för bild av sin museiorganisation? Ser de organisationen som en maskin, ett levande system, eller ser de en holografisk struktur? Nu ställs frågan inte så, men genom att fråga om mål och struktur, resultat och styrning växer det fram en implicit bild av vilken metafor som styr respondenternas tänkande kring begreppet organisation.

\section{Mål och struktur}

Hur ser man i museisystemet på de kulturpolitiska målen, fungerar de som styrinstrument, kan de användas för att fatta beslut på museet? Enkäten undersökte detta med hjälp av några kontroversiella påståenden. Svaren presenteras i tabell 1 nedan. Men vi börjar från grunden, frågan är om mål över huvud taget behövs? Det kanske låter trivialt när det sägs så tillspetsat, men det finns många som menar att målstyrningens idé är omöjlig (Rombach 1990). Den går inte att genomföra praktiskt, och den vilar på svag teoretisk grund. Det må vara hur det vill med det (i det här sammanhanget) men det leder till att organisationers behov av mål kan variera.

Svaren i tabell 1 visar att det finns en stor uppslutning i museisystemet kring målformuleringsarbetet som sådant. Hela 
KIM FORSS

\begin{tabular}{|c|c|c|c|c|c|}
\hline Påstående & $\begin{array}{l}\text { Håller med } \\
\text { till fullo }\end{array}$ & $\begin{array}{l}\text { Håller med } \\
\text { till del }\end{array}$ & Vet ej & $\begin{array}{l}\text { Håller inte } \\
\text { riktigt med }\end{array}$ & $\begin{array}{l}\text { Håller absolut } \\
\text { inte med }\end{array}$ \\
\hline $\begin{array}{l}\text { De kulturpolitiska målen } \\
\text { är en bra utgångspunkt } \\
\text { för praktiska beslut om } \\
\text { verksamheten }\end{array}$ & 30 & 43 & 9 & 12 & 6 \\
\hline $\begin{array}{l}\text { När man står inför svåra } \\
\text { beslut om vad som skall } \\
\text { prioriteras på museet ger } \\
\text { de politiska målen god } \\
\text { vägledning }\end{array}$ & 12 & 35 & 12 & 25 & 17 \\
\hline $\begin{array}{l}\text { Om man arbetar mera } \\
\text { systematiskt med målen } \\
\text { kan man lösa många } \\
\text { problem }\end{array}$ & 24 & 39 & 16 & 16 & 5 \\
\hline $\begin{array}{l}\text { Klara och tydliga mål är } \\
\text { en förutsättning för } \\
\text { effektivt arbete }\end{array}$ & 78 & 20 & 0 & 1 & 0 \\
\hline
\end{tabular}

Tabell 1. Om behovet av mål och målstyrning (procentuell andel). Källa: Museiutredningens enkät till anställda på museerna.

98\% håller med om påståendet "klara och tydliga mål är en förutsättning för effektivt arbete", även om $20 \%$ håller med till viss del. Det är något färre som håller med om att de kulturpolitiska målen är en bra utgångspunkt för praktiska beslut; 73\% för och $18 \%$ mot.

Notera dock att det är fler som önskar klara och tydliga mål. Här har man tappat $20 \%$ av respondenterna. Ännu något sämre är det vad gäller att använda målen för att prioritera verksamheter. Det är $47 \%$ som anser att målen då kan vara till någon vägledning, medan $42 \%$ anser att de knappast kan vara till någon hjälp. Men $63 \%$ anser att målen kan lösa många problem om man arbetar mera systematiskt med dem.
Frågan är dock hur svaren skall värderas; men det är fler som ser positivt på målen (dvs instämmer i påståendena) än tvärtom. Vi tolkar svaren så att de visar att respondenterna anser att mål är viktiga och behövs, de kulturpolitiska målen är en bra utgångspunkt, men kanske inte alltid användbara vid svåra prioriteringsbeslut. Dock kan de vara bra om man arbetar mera systematiskt med dem.

Frågan om mål och styrning hänger samman med den om frihet och nyttan av att själv utforma sitt arbete (tabell 2). Något odefinierat kan man säga att museerna arbetar med kultur, att de därför är kulturinstitutioner, och bör ha en betydande frihet från politisk styrning. Det är 
en åsikt som de flesta respondenter skriver under på; $78 \%$ till fullo och ytterligare $16 \%$ till del. Varför bör museernas ställning som fria kulturinstitutioner värnas och vad innebär det? Ja, enkätsvaren ger inga heltäckande svar på frågan.

\section{Om institutionernas fribet}

Vi har sett att det finns en bred uppslutning bakom de kulturpolitiska målen. Det kan tyckas vara ett dilemma; tydliga mål är en förutsättning för effektivt arbete och man vill arbeta mera systematiskt med målen; men samtidigt vill man vara "fria". Hur löses dilemmat, har det med det konstnärliga innehållet att göra? Inte i så stor utsträckning - som tabellen visar är det inte alls lika många som håller med om att sådana yrken inte bör styras poli- tiskt, som de som anser att museernas fria ställning bör värnas.

Kanske står svaret att finna i en omsorg om effekterna av arbetet, och i uppfattningen att det blir bättre om inte politiker och ämbetsmän lägger sig i? Till dels är det så. En majoritet håller med om de två påståenden som för fram tanken att resultatet blir bäst om besluten fattas närmast den som utövar verksamheten. Men de tillfrågade svarar inte lika oreserverat "ja" som på den första frågan, om de fria kulturinstitutionerna.

Om nu politisk styrning accepteras så länge den ger museerna stor frihet att själva utforma sitt arbete och ge det ett konstnärligt innehåll, vad sägs då om annan styrning; t.ex. av marknadskrafterna. Påståendet om att mera affärsmässig styrning

Tabell 2. Om kulturinstitutionernas frihet (procentuell andel). Källa: Museiutredningens enkät till anställda på museerna.

Påstående

Museernas ställning som fria kulturinstitutioner bör värnas

Yrken med konstnärligt innehåll bör inte styras politiskt

Museerna borde styras mera affärsmässigt

Frihet att själv utforma sitt arbetsinnehåll ger bäst resultat

De bästa besluten om en verksamhet fattas av den som är direkt ansvarig

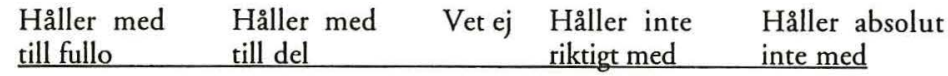

78

25

26
16

32

34

53

43 
108 vore bra delar de svarande nästan mitt itu. Knappt hälften håller med och drygt hälften håller inte med. De som absolut inte håller med är dock dubbelt så många som de som håller med till fullo.

\section{Om resultat och utvärdering}

Hur är det med återföringen från verksamheten - kunskap om effekterna är ju en förutsättning både för den politiska styrningen och för ett mera affärsmässigt agerande. Tabell 3 redovisar resultat om detta. Det finns en stor uppslutning kring att resultatkontrollen är för svag och att det behövs flera utvärderingar av verksamheten. Även om relativt många markerar "vet ej", är det en stor majoritet som håller med, många av dem i positioner med ledning och ansvar för verksamheten. Om de anser att resultatkontrollen är dålig så är den sannolikt det.

Det finns inte lika starkt medhåll för kopplingen mellan underlag och krav. Även om en majoritet på $51 \%$ håller med,

Tabell 3. Om resultat och utvärdering (procentuell fördelning). Källa: Museiutredningens enkät till anställda på museerna.

Påstående

Håller med till fullo

Håller med till del

Vet ej Håller inte riktigt med

Håller absolut

Resultatkontrollen är

för dålig bland museerna

44

30

14

8

4

Det behövs mera

utvärderingar

som underlag

för beslut

42

35

10

12

2

Brist på underlag gör det omöjligt att ställa krav på museerna

30

15

24

Gediget yrkeskunnande behöver inte marknadsföras

3

10

4

31

52

Museerna måste locka till sig folk med roliga aktiviteter

Barn och ungdom făr en alltför stor del av museernas resurser
13

6

38

41 
så finns det många som menar att det går att ställa krav utan att få något underlag om verksamhetens resultat. I och för sig är det förstås sant, men på längre sikt kan det ju leda till orealistiska eller intetsägande krav - om man inte har någon uppföljning av vad som hänt.

De tre sista påståendena i tabell 3 följer upp frågan om affärsmässighet som visades i tabell 1 . Som vi ser är respondenterna väl medvetna om betydelsen av marknadsföring, och det finns mycket lite uppslutning kring tanken att det räcker med att göra bra saker för att publiken skall komma. Om sedan den insikten alltid är omsatt i praktisk handling är förstås en annan sak. En stor andel av de tillfrågade instämmer också $\mathrm{i}$ att museerna bör försöka dra till sig folk med roliga aktiviteter, dvs satsningar på barnrum, extra visningar, kafé och restauranger, tävlingar, musik, mm är väl förankrade.

Återigen är det viktigt att begrunda vilken grupp de svarande representerar; huvudsakligen är de akademiker, många med forskarbakgrund och med blandade roller i museerna. Det är, i detta avseende, inte en inåtvänd eller marknadsfrånvänd grupp. De flesta tar avstånd från att barn och ungdomar skulle få för stor del av museernas resurser.

Den styrning, resultatkontroll och verksamhet vi talar om, äger rum innanför ramen av en organisationstruktur. Strukturen består av ett antal museienheter som är sammanlänkade med varandra genom arbetsfördelning och samordning. En sådan struktur, vare sig det gäller museer eller andra verksamheter, kan vara klar och tydlig eller mera ambivalent. I organisationsteorins barndom utgick man från byråkratiska ideal skapade av Max Weber eller mekanistiska synsätt från den amerikanska Taylorismen, dvs med koppling till det som ovan benämndes som maskinmetaforen. Idag finns en mera sofistikerad syn på samspelet mellan människor och organisationer, där bl.a. den givna organisationskulturen har stor betydelse för de regler som etableras inom en organisation.

\section{Om osäkerhet}

En av de centrala frågorna rör hur man hanterar osäkerhet, och i vad mån organisationens medlemmar är beredda och villiga att hantera osäkra situationer; t.ex. osäkerhet om vem som har ansvar, vem som bestämmer, vilka regler som gäller, vad som är tillåtet och vad som är förbjudet. Tabell 4 redovisar ett antal påståenden som är relaterade till osäkerhet, eller rättare sagt till hur man kan ta bort eller hantera osäkerhet i en organisation.

Svaren talar egentligen för sig själva. Vi finner en stark uppslutning kring en ganska formell och statisk syn på organisationen. Förändring ses som problematisk; det är många som instämmer $\mathrm{i}$ att människor blir handlingsförlamade och villrådiga i en sådan organisation. Likaså vill man ha klara och tydliga gränser mellan organisationer. Hela $88 \%$ instämmer i att annars blir det anarki och kaos.

Svaren ger också uttryck för en relativt hierarkisk syn på organisationen. 53\% menar att struktur är till för att få veta vem som bestämmer. $46 \%$ menar att den bästa samordningen sker genom att någon bestämmer. Eftersom samma enkätfrågor ställts i andra sammanhang (Hofstede, 1982, Laurent, 1986) finns det ett jämförelsematerial, och det visar att i Sverige sällan mer än $5-15 \%$ av respondenterna 
KIM FORSS

\begin{tabular}{|c|c|c|c|c|c|}
\hline Påstående & $\begin{array}{l}\text { Håller med } \\
\text { till fullo }\end{array}$ & $\begin{array}{l}\text { Håller med } \\
\text { till del }\end{array}$ & Vet ej & $\begin{array}{l}\text { Håller inte } \\
\text { riktigt med }\end{array}$ & $\begin{array}{l}\text { Håller absolut } \\
\text { inte med }\end{array}$ \\
\hline $\begin{array}{l}\text { Den främsta anledningen } \\
\text { till att man har en } \\
\text { organisationsstruktur } \\
\text { är att man făr veta } \\
\text { vem som bestämmer vad }\end{array}$ & 27 & 30 & 10 & 24 & 10 \\
\hline $\begin{array}{l}\text { Det bästa sättet att } \\
\text { samordna verksamheter } \\
\text { är att någon bestämmer } \\
\text { vad som skall göras } \\
\text { och av vem }\end{array}$ & 18 & 28 & 9 & 27 & 18 \\
\hline $\begin{array}{l}\text { En organisationsstruktur } \\
\text { som är svåröverskådlig } \\
\text { leder till anarki och kaos }\end{array}$ & 45 & 33 & 8 & 12 & 3 \\
\hline $\begin{array}{l}\text { I en organisationstruktur } \\
\text { som förändras ofta blir } \\
\text { människor villrådiga och } \\
\text { handlingsförlamade }\end{array}$ & 44 & 37 & 4 & 12 & 3 \\
\hline $\begin{array}{l}\text { Det är inte bra om en } \\
\text { person i en befattning } \\
\text { har två chefer som kan } \\
\text { vilja olika saker }\end{array}$ & 75 & 17 & 2 & 3 & 2 \\
\hline
\end{tabular}

Tabell 4. Om osäkerbet i organisationen (procentuell fördelning). Källa: Museiutredningens enkät till anställda på museerna.

instämmer i dessa påståenden. De tillfrågade var chefer i näringsliv och förvaltning.

Misstänksamheten mot dubbla rapporteringsvägar är utbredd. 93\% tar avstånd från att kunna ha flera instanser att rapportera till. Det skulle innebära att matrisorganisationer; dvs organisationer som t.ex. kan bygga på både geografisk och funktionell arbetsfördelning (fast till priset av dubbla rapporteringsvägar) inte är lämpliga i museivärlden. Svaret är ett uttryck för att man vill ha klarhet och säkerhet; det är ingen tvekan om att matrisorganisationer är svåra, röriga och ofta dyra organisationer - men de blir föränderliga och därmed anpassningsbara till skiftande krav och behov. Ofta är ambivalens och ett visst mått av kaos priset man får betala för flexibilitet. Men de som besvarat enkäten verkar knappast beredda att betala det priset.

\section{Sammanfattning}

Undersökningen här bygger på drygt 400 enkätsvar från anställda $\mathrm{i}$ museisystemet. De som svarat har ofta befattningar i 
museiledningen och de är akademiker. Medelåldern ligger mellan 40 och 50 år, och det är något flera kvinnor än män. Gruppen utgör vad som skulle kunna kallas ett "ledande delsystem" inom museivärlden, och svaren bör tolkas utifrån denna grupps specifika erfarenheter och intressen.

Respondenterna anser att mål är viktiga och behövs. De flesta anser det viktigt att museernas ställning som fria kulturinstitutioner värnas, och många av svaren ger uttryck för att man ser skeptiskt på politisk styrning. Museets prestation blir bäst desto närmare verkligheten besluten sker, och konstnärligt arbete bör ges stor frihet.

Samtidigt finns det många som anser att verksamheten bör utvärderas mera och att man vet för lite om effekterna; och detta är en förutsättning för att man skall kunna ställa krav på museerna. Borde museerna bli mera affärsmässiga? Ja, det är en fråga som klyver gruppen, knappt hälften svarar ja, men resten är emot. Enkäten visar dock att många vill satsa på publiken med olika typer av aktiviteter, och det finns en utbredd förståelse för behovet av aktiv marknadsföring.

Svaren ger uttryck för en stark uppslutning kring en formell och statisk syn på organisationen. Förändring ses som något problematiskt och de svarande vill ha klara och tydliga gränser mellan organisationer, annars blir det anarki och kaos. Synen på organisation är hierarkisk, strukturen är till för att få veta vem som bestämmer. Det antyder att organisationen har svårt att hantera osäkerhet, och därmed blir den inte flexibel och anpassningsbar. Frågan är förstås om detta är önskvärda eller nödvändiga egenskaper - om så är fallet behövs omfattande attitydförändringar avseende organisationsfrågor.
I den mån man kan dra några slutsatser om respondenternas implicita modeller av vad en organisation är, så dominerar bilden av organisationen som en maskin. I alla de väsentliga variablerna som refereras här finns det en kraftig uppslutning kring det som är den klassiska management-teorins kunskapsarv, dess råd och recept. Det finns ingenting som tyder på att de senaste årtiondenas kunskapsutveckling kring holografiska organisationer är omsatt i värderingar och synpunkter som kommer till uttryck inom ramen för enkäten. Det finns inte heller så många tecken på att den andra metaforen - organisationen som levande system - omsatts i praktiska värderingar och attityder. Istället har maskinmetaforen en kraftig förankring i museisystemets ledande skikt och vad man där tänker om organisationsfrågor.

Det är intressant att notera att museerna här skiljer sig från andra organisationer. Inom det privata näringslivet finns förstås många skilda metaforer $\mathrm{i}$ företagsledarnas tankar, och det varierar mycket mellan branscher (Lane och DiStefano, 1992; Laurent, 1986; Sjögren och Jansson, 1994). Även inom förvaltningen finns många skilda traditioner (Sköldberg, 1990). Det finns dock mycket som tyder på att företag och andra organisationer i snabbt föränderliga, kunskapsintensiva miljöer tenderar att ha en mera holografisk bild av organisationen. Frågan är dock först $\mathrm{i}$ vad mån den bild som växer fram här är sann, och vad den i så fall har för konsekvenser.

\section{FINNS IMPLICITA MODELLER AV ORGANISATIONER?}

En forskare kan förstås inte gå runt och fråga vad människor har för implicita 
112 modeller av organisation. De flesta har i praktiken element av flera - utan att vara medvetna om det. I genomgången ovan har jag dock tolkat de museianställdas svar så att den dominerande implicita modellen av organisation är den av en maskin. Deras tänkande kring organisationsfrågor präglas av en mekanistisk metafor. Därmed inte sagt att det är den enda förekommande metaforen, och det är absolut inte sagt att den mekanistiska bilden gör sig gällande på andra områden. Frågan är om den egentligen stämmer ens på organisationsområdet?

Om jag tog min utgångspunkt i museernas verksamhet och mot bakgrund av museiuppdraget, storleken och omfattningen av organisationerna, och deras kontakter med omvärlden; tänkte efter vad för slags bild av organisationen som borde vara förhärskande - då skulle jag a priori ha trott att den holografiska organisationsmodellen skulle vara den vanligaste. Både explicit och implicit. Museerna är små organisationer, de lever $\mathrm{i}$ en snabbt föränderlig omvärld, med nära kontakter till publik, många anställda har en humanistisk bakgrund, det är en kunskapsintensiv verksamhet.Visserligen skulle jag trott att det skilde sig åt mellan museer, och kanske även att metaforen «det levande systemet» skulle vara vanligt förekommande. Kanske skulle maskinmetaforen förekomma på några äldre, större och mera trögrörliga myndigheter. Men jag hade förväntat starka inslag av den holografiska modellen även där.

Nåväl, i den mån jag testat detta som en hypotes hade jag haft fel, men sådana var i alla fall mina förväntningar. Kan det vara så att svaren är vilseledande? Enkäten var utsänd av en parlamentarisk utredning som särskilt hade att granska mål och samhällsuppdrag. Ordet utvärdering nämndes i utredningsdirektiven, och alla känner till det stora intresset för mål- och resultatstyrning inom den statliga förvaltningen.

Kanske är det inte så sannolikt att man då i svaren på en enkät uttrycker stor skepsis inför en allmänförståelse av dessa begrepp? Kanske är det inte så troligt att man instämmer $\mathrm{i}$ kontroversiella påståenden av arten ovan, som kanske också verkar dumma. Skulle en parlamentarisk utredning kunna tycka det är rimligt att respondenterna inte ser något behov av en klar formulering av verksamhetens mål?

Det kan också vara så att respondenterna, när de besvarar enkäten, omedvetet växlar över och svarar inom ramen för maskinmetaforen. Utan att riktigt tänka sig för, tar man för givet att utredningen arbetar på ett sådant sätt, och själv tänker man då också inom sådana ramar. Men i praktiken håller man sig inte med en organisationsmetafor, och kanske är det praktiska handlandet mera likt det som skulle kännetecknas av den holografiska metaforen.

Kanske krävs det också relativt mycket kunskap om organisationsteori för att tillägna sig de synsätt som finns inom de andra metaforerna, särskilt då vad gäller den holografiska. Statsförvaltningen i sin helhet präglas av maskinmetaforen, som t.ex. hela budgetprocessen och inte minst mål- och resultatstyrningen ger uttryck för. Det skall rätt mycket sakkunskap till för att bryta mot etablerade synsätt, och säkert saknar många inom museerna den kunskapen.

Det finns med andra ord anledning att vara skeptisk mot museiutredningens 
enkätsvar och mot min tolkning av dem. Men det är ändå en vägvisning, och det kan finnas anledning att kritiskt pröva vilket slags tänkande om organisationer som är förhärskande bland museernas chefer och personal.

\section{METAFORENS KONSEKVENSER}

Om det nu är så att maskinmetaforen präglar museichefernas och de anställdas bild av en organisation, vad får det för konsekvenser? Det är absolut inte något hinder att skapa väl fungerande organisationer, och kanske är det så att många skulle känna sig mest hemma i organisationer som på det sättet vore trygga, stabila, klara och tydliga, som levererar sina "produkter» (utställningar, föredrag, välvårdade förråd och lager).

Men samtidigt har den typen av organisationer som är uppbyggda efter maskinmetaforens ideal sina begränsningar, även om de skulle fungera enligt ritningarna. Ett av de allvarligaste hindren är att den skapar organisationsformer som har svårt att anpassa sig till förändringar. Inledningsvis pekade jag på debatten kring museernas väsen och samhällsuppdrag. Många av de förslagen innebär ett relativt omfattande brott med bilden av museet som i huvudsak en organisation för att vårda och förvara föremål från en svunnen tid.

Remissvaren på museiutredningen visar tydligt att en stor del av museernas ledningar har svårt att anamma de praktiska konsekvenserna av den förnyelse av museiuppdraget, av vidhängande organisationsförändringar och arbetssätt, som utredningen föreslår. I det här sammanhanget behöver jag inte diskutera om för- slagen är rätt eller fel, men i den mån en nyorientering faktiskt behövs, så är förekomsten av en implicit maskinmetafor ett hinder för att verkställa förändringsarbetet.

Maskinmetaforen bidrar till att skapa byråkratiska organisationer. Många organisationer behöver omfattande byråkrati, inte minst för att det kan ge transparens, rättvisa och tillförlitlighet. Men det är inte säkert att museer behöver vara byråkratier. Ordningsfrågor kring ledning, styrsystem, resultatredovisning osv kan komma att ta betydande resurser i anspråk. Där resurser är knappa innebär det ett dubbelt slöseri; för det första genom den omedelbara effekten av ianspråktagna medel, och för det andra genom förlorade alternativa möjligheter att använda organisationens resurser.

Det sägs ofta att maskinmetaforen kan leda till ett kortsiktigt tänkande kring instrumentella värden snarare än organisationens ursprungliga mål. Inom ramen för museiutredningen diskuterades målen och utredningen fann att det främsta målet för museiverksamheten är bildning. Utredningen argumenterar att allt annat är underordnat detta mål.

Remissvaren på museiutredningen visar, att de flesta institutioner har betydligt mera kortsiktiga mål, främst vad gäller vård och insamling. För dem som ser organisationen som en maskin är det naturligt att tänka på relativt enkla och endimensionella mål. Organisationens naturliga uppgift är att nå dessa. Det finns heller inte någon större tolerans för en komplicerad och ambivalent målstruktur, och inte heller för mera begreppsmässigt svåra och långsiktiga mål.

Museerna är organisationer som spänner 
114 över flera verksamhetsfält. De lever i en snabbt föränderlig miljö, och de har att konkurrera med en lång rad andra evenemang om medborgarnas gunst och intresse. De är kunskapsorganisationer, och som sådana behöver de ha en stor förmåga till organisatoriskt lärande. Men oförmågan att lära är just en av de största svagheterna med den maskinlika organisationen.

Den holografiska organisationen däremot är uppbyggd just med lärande som ett främsta syfte, och med andra «designvariabler» utformade just för att främja lärande. Kan museerna som organisationer lära i tillräcklig omfattning så länge som de flesta befattningshavare har maskinen som metafor för organisation - och handlar därefter? Säkert inte. För att få en organisation som lär måste man utforma strukturer och arbetssätt som främjar lärande, och det gör man inte inom ramen för maskinmetaforen.

\section{SLUTSATSER}

Museernas organisationstruktur är ett resultat av människors strävan att kollektivt minnas. Utmaningen ligger $\mathrm{i}$ att finna en roll för de statliga museerna som gör dem till en verkligt fungerande del av det kollektiva minnet. Men om museerna skall ta sitt bildningsuppdrag på allvar krävs en ny syn på organisationen. Detsamma gäller om de skall fungera som mötesplatser, debattfora eller vad det nu finns för andra visioner av museernas syfte och arbetssätt.

Inledningsvis skisserades tre huvudtyper av implicita organisationsmodeller; organisationen som (1) maskin, (2) levande system eller (3) hologram. De är inte varandra uteslutande, och de flesta av oss har väl delar av alla tre i våra bilder av vad en organisation är. Materialet från museiutredningen pekar dock på att många i museisystemet, särskilt på chefsnivå, bär med sig en bild av organisationer som maskiner i sitt intellektuella bagage.

Maskinmetaforen har många starka sidor, men det är mycket som talar för att den är olämplig som förebild inom en snabbt föränderlig, kunskapsintensiv verksamhet som museernas borde vara. De som låter sin handling styras av en implicit maskinmetafor lär ha svårt att hantera de krav på flexibla, komplicerade strukturer som verksamheten kräver. Organisationen får $\mathrm{i}$ sin tur svårt att lära och anpassa sig till sin miljö, och de anställdas behov av stimulerande och omväxlande arbetsuppgifter blir svåra eller omöjliga att tillgodose.

Vad kan då göras för att förändra den metafor av organisationer som styr (och begränsar) museiutvecklingen? Det är en alltför svår fråga att ta upp här. En första uppgift är dock att konstatera om den bild som antytts ovan, och som är en naturlig hypotes till följd av museiutredningens undersökningar, är riktig eller ej. Om så är fallet, är det en god hjälp att man har en diagnos av problemet. Enbart genom att uppmärksamma tänkandets roll för handlingen kan man skapa perspektiv på organisationsfrågor.

I den mån många har maskinmetaforen som bild för organisationen så är det inte ett frivilligt val, utan reflekterar snarare brist på kunskap och kontakt med utveckling inom organisationsteorin. Snarare än att sträva vidare med organisatoriska lösningar som har små möjligheter att komma åt kärnan av problemet, kan man då via kommunikation, utbildning, personal- 
utveckling öka kunskapen om sambandet mellan en typ av organisation och en uppgift i samhället.

\section{SUMMARY \\ From Machine to Hologram - Thoughts about the Organisation of Museums}

The author was one of two secretaries working for the Committee responsible for the state report Memory and Education. In this paper he discusses the connection between the metaphors for organisational structures prevalent among leaders and employees in museums and the demands made on the structures as a result of the nature of the museum mission and its working methods. The material gathered by the State Committee indicates that many museum curators apply the machine metaphor to their institutions. However in many circumstances such a metaphor is unsuited to the activities a museum should unfold responding to the rapid change in the surrounding world.

\section{LITTERATUR}

Argyris, C. and Schon, D. (1978) Organizational Learning: A Theory of Action Perspective. MA: Addison-Wesley

Babbage, C. (1832) On the Economy of Machinery and Manufactures. London: Charles Knight

Beer, S. (1972) Brain of the Firm. New York: Herder \& Herder

Emery, F.E. och Trist, E.L. (1973) Towards a Social Ecology. New York: Plenum Press

Fayol, H. (1949) General and Industrial Management. London: Pitman

Hofstede, G. (1982) Culture's Consequences: International Differences in Work-Related Values. London: Sage

Kuhn, T. (1970) The Structure of Scientific
Revolutions. Chicago: Chicago University Press
Management Behaviour. Boston: PWS-Kent

Laurent, A. (1986) Management à la Suédoise Quelques Contrastes Ideologiques. INSEAD Working paper

Lawrence, P.R. och Lorsch, J.W. (1967)

Organization and Environment. MA: Harvard

University Press

Mainzer, K. (1994) Thinking in Complexity: The Complex Dynamics of Matter, Mind and Mankind. Berlin: Springer Verlag

Maslow, A.H. (1943) «A Theory of Human

Motivation». Psychological Review, 50: 370-396

Mayo, E. (1933) The Human Problems of Industrial Civilization. New York: Macmillan

Mintzberg, H. (1979) The Structuring of Organizations. Englewood Cliffs, NJ: PrenticeHall

Mooney, J.C. och Reilly, A.P. (1931) Onward Industry. New York: Harper Row

Morgan, G. (1986) Images of Organization. London: Sage

Rombach, B. (1991) Det går inte att styra med mål. Lund: Studentlitteratur.

SOU 1994: 51. Minne och bildning. Museernas uppdrag och organisation. Museiutredningens betänkande

Sjögren, A. och Janson, L. (1994) Culture and Management in a changing Europe. The Swedish Immigration Institute and The Stockholm School of Economics. Stockholm

Sköldberg, K. (1990) Administrationens poetiska logik. Lund: Studentlitteratur

Smith, A. (1776) An Inquiry Into The Wealth of Nations. London: Stratton and Cadell

Taylor, F. (1911) Principles of Scientific Management. New York: Harper \& Row

Waldrop, M.M. (1992) Complexity: The Emerging Science at The Edge of Order and Chaos. New York: Touchstone

Weber, M. (1947) The Theory of Social and 
KIM FORSS

116 Economic Organization. London: Oxford University Press

Wilber, K (1982) The Holographic Paradigm and

Other Paradoxes. London: New Science Library

Kim Forss är ekonomie doktor. Han var en av sekreterarna $i$ den nyligen publicerade museiutredningen. Sedan 1989 är han delägare i konsultforetaget Andante $A B$, med huvudsaklig inriktning på forskning, utbildning och raid om styrning, samordning och utvärdering $i$ komplexa organisatoriska miljöer. Adr: Bisp Thomas väg 8, S-645 34 Strängnäs Fax +46-15219700 